\title{
Transition between terrestrial-submerged walking and swimming revealed by Early Permian amphibian trackways and a new proposal for the nomenclature of compound trace fossils
}

\author{
Fabio M. Petti ${ }^{\mathrm{a}, 1}$, Massimo Bernardi a,b,1, Miriam A. Ashley-Ross ${ }^{\mathrm{c}}$, Fabrizio Berra ${ }^{\mathrm{d}}$, Andrea \\ Tessarollo $^{\mathrm{d}}$, Marco Avanzini ${ }^{\text {a }}$ \\ ${ }^{a}$ MUSE - Museo delle Scienze di Trento, Corso del Lavoro e della Scienza 3, 38123 Trento, Italy ${ }^{\text {b }}$ \\ School of Earth Sciences, University of Bristol, Bristol BS8 1RJ, UK \\ ${ }^{\mathrm{c}}$ Department of Biology, Box 7325, Wake Forest University, Winston-Salem, NC 27109 USA d Dipartimento di \\ Scienze della Terra “A. Desio", Università di Milano, Via Mangiagalli 34, 20133 Milan, Italy
}

\begin{abstract}
Exceptionally preserved Early Permian tetrapod trackways from the Orobic Basin (Central-Western Southern Alps) offer a unique opportunity to investigate in detail locomotion in fossil vertebrates that lived on continental European landmasses. Herein are reported the results of a study on several tetrapod trackways that display a large variety of behavioral, gait and substrate related extramorphologies. They clearly document the transition from terrestrial-underwater walking to swimming and are assigned to the compound ichnotaxon Batrachichnus C Lunichnium. The use of the "C" symbol is here introduced for the first time as nomenclatural indication of a Compound trace. Producers were probably small-sized temnospondyl or lepospondyl (microsaurs) amphibians. Comparisons with living urodelan anatomy and mechanics provide evidence for conservatism of locomotor mechanics in evolutionary history among amphibians. The derived model for locomotor kinematics in Early Permian amphibians provides a reference for interpreting transitional land-to-water trackways. The shift from walking to swimming behavior in early tetrapods, as in extant urodelan amphibians, is described as a complex balance between different dynamics.
\end{abstract}

Keywords: Locomotion, Temnospondyl, Footprints, Batrachichnus C Lunichnium, Compound trace fossils, Nomenclature

\section{Introduction}

Fossil tracks and trackways provide evidence of locomotory behavior in extinct organisms and their analysis adds significantly to the study of biomechanical performance in fossil limbed vertebrates (tetrapods). Tracks are complex structures that result from the physical interaction between the trackmaker and the substrate (e.g. Manning, 2004). During ground contact (i.e. footfall) and during recovery, any movement of the foot that involves contact with the sediment is recorded as a footprint plus a whole range of extramorphologies. Type and amount of anatomical details preserved by this complex of tracks and extramorphologies result from locomotor dynamics (e.g. digit scratches, tail drags). They thus can only be investigated after filtering out the effects of the substrate physical properties (e.g. moisture content) and the uncertainties related to the behavior and identity of the trackmaker (e.g. substraterelated or gait-controlled differences can be misinterpreted as producer-related). Herein are described a series of trackways from the Pizzo del Diavolo outcrop (Lower Permian, Bergamo, north Italy) that includes many morphological variants of tracks related to preservational and behavioral variation, exceptionally recorded on single trackways (i.e. compound trace sensu Pickerill and Narbonne, 1995) produced by a single track-maker.

Comparison with living tetrapod anatomy and mechanics constitute the most parsimonious approach to interpret past behaviors, in particular when no detailed studies on the appendicular anatomy and mechanics in the fossil group are available. Locomotor studies on living amphibians (Ashley-Ross and Bechtel, 2004; Ijspeert et al., 2007; Ashley-Ross et al., 2009) and analysis of their trackways left on different types of substrate (McKee, 1947; Peabody, 1959; Brand, 1979; Fichter, 1982, 1983; Brand, 1996) provide useful tools to understand the relationships between the kinematics of locomotion and preservation styles of fossil trackways. By integrating these approaches, a new model for locomotor kinematics in Early Permian amphibians is derived, providing a reference for interpreting transitional land-to-water trackways. 


\section{Geology of the study area}

The Lower Permian succession of the Southern Alps is represented by an array of continental deposits resting on the Variscan basement: volcanic, alluvial and palustrine-lacustrine deposits occur in distinct, tectonically-driven basins (Orobic Basin, Collio Basin, Tione Basin, Tregiovo Basin, the Forni-Avoltri Basin and the Pramollo Basin; Cassinis and Perotti, 1994; Perotti, 1999; Cassinis et al., 1988; Cassinis, 2007). The stratigraphic architecture of the deposits preserved in these basins is diverse, reflecting different depositional settings and tectonic evolution in each of the Early Permian basins of the Southern Alps. Due to the scarce paleontologic content, deposition in these basins is generally constrained by radiometric data, which indicate a timetransgressive deposition from about 283 to about 270 Ma (Schaltegger and Brack, 1999; Marocchi et al., 2008). The Lower Permian succession of the Southern Alps is very poor in skeletal remains of fossil vertebrates while tetrapod tracks are widespread (Geinitz, 1869; Curioni, 1870; Dozy, 1935; Haubold, 1971; Ceoloni et al., 1987; Conti et al., 1991; Haubold, 1996; Conti et al., 1997; Santi, 1999; Cassinis et al., 2000; Nicosia et al., 2000; Gianotti et al., 2001; Nicosia et al., 2001; Santi and Krieger, 2001; Gianotti et al., 2002; Arduini et al., 2003; Santi, 2003, 2005; Avanzini et al., 2007, 2008; Bernardi and Avanzini, 2011).

The study area belongs to the Orobic Basin (Lombardy, N Italy), one of the largest Permian basins of the Southern Alps (Cadel et al., 1996). In this basin the lithostratigraphic subdivision historically followed that of the Collio Basin, but major differences in the facies distribution and vertical evolution led to the revision of the lithostratigraphic nomenclature (Boriani and Bini, 2012; Jadoul et al., 2012). As a consequence the term Collio Formation was replaced in the Orobic sector by a new lithostratigraphic nomenclature better describing the sedimentary succession. The sedimentary succession between the Variscan Basement and the unconformably overlaying Verrucano Lombardo Formation is now referred to as the Laghi Gemelli Group (Fig. 1), which is subdivided into two overlying formations: the Cabianca Volcanite (below) mainly constituted by pyroclastic flows (Lower Collio Formation Auct.; Cadel et al., 1996; Berra and Felletti, 2011), and the Pizzo del Diavolo Formation (above), consisting mostly of continental clastics with minor intercalations of ignimbritic flows and tuffs (Upper Collio Formation Auct.; Cadel et al., 1996; Berra and Felletti, 2011). The evolution of this succession was controlled by volcanic and tectonic activity (De Sitter and De SitterKoomans, 1949; Casati and Gnaccolini, 1967; Cadel et al., 1996; Cassinis et al., 2000; Berra and Felletti, 2011), both recorded by the facies distribution.

The Pizzo del Diavolo Formation (Berra and Felletti, 2011), more than $1000 \mathrm{~m}$ thick, consists of a complex association of continental deposits, ranging from coarse conglomerates at the fault-controlled borders of the basin to thick sandstone bodies and, more distally, dark pelites with local intercalations of microbial carbonates. Volcanic activity is reduced and documented by tuff layers (up to a few tens of meters thick) occurring at different stratigraphic levels. The Pizzo del Diavolo Formation is covered by the Late Permian Verrucano Lombardo (Lopingian according to Boriani and Bini, 2012), with a low-angle angular unconformity.

According to facies distribution and associations, the Pizzo del Diavolo Formation is subdivided into three main lithozones (Berra and Felletti, 2011) which can be easily separated in the southern part of the basin: the lowermost is composed of conglomerates passing laterally to sandstones and distally to silt and shales (Lower Lithozone), the middle part is pelitic, with carbonates (Pelitic Lithozone) while the uppermost one is represented by alternating sandstone, pelites and volcanic flows (Upper Lithozone) (Berra and Felletti, 2011; see also Casati and Gnaccolini, 1967; Cadel et al., 1996; Sciunnach, 2001). The finegrained facies of these three lithozones are commonly characterized by the preservation of abundant reptiles and amphibian tracks, that have been mainly reported from the middle-upper portion of the unit (Conti et al., 1999; Nicosia et al., 2000; Santi and Krieger, 2001; Ronchi et al., 2005; Berra and Felletti, 2011; Boriani and Bini, 2012; Jadoul et al., 2012). The described trackways come from a loose block of heterolithic deposits consisting mostly of fine-grained sandstones and siltstone-shale, deriving from the northern slope of the valley, where the presence of trackways was documented by Ronchi et al. (2005). The facies are typically characterized by parallel to ripple laminations, indicating sedimentation by low-energy currents on flat depositional surfaces. The presence of abundant mud cracks and vertebrate trackways indicates the episodic flooding of the depositional surface. Sedimentological evidence suggests that deposition occurred close to the depocentral area of the basin, where episodic floods delivered fine-grained sediments and provided waters for the development of ephemeral shallow lakes. This facies is typical of the upper part of the "Lower Lithozone" of the Pizzo del Diavolo Formation, so that the stratigraphic position of the blocks containing the vertebrate trackways can be confidently assessed.

\section{Material and methods}

The herein described material is constituted by nine trackways (PD-1 to PD-9; Fig. 2) with up to six consecutive couples of manual and pedal imprints, exclusively preserved as concave epireliefs (sensu Leonardi, 1987). All the trackways were outlined on transparent acetate following standard operating procedures (Leonardi, 1987). Kinematic study of the described trackways is based on analysis 
of the following published videos: Taricha torosa (Ashley-Ross and Bechtel, 2004; Ashley-Ross et al., 2009; available at http://www.wfu.edu/ rossma/ Ashley-Ross_Lab/Newt_Movies.html), Pleurodeles waltlii (Ijspeert et al., 2007 supplemental material; available at http://birg2.epfl. ch/movies/full/mov/salam_robot/1138353s1.mov).

\section{Ichnotaxonomic issues}

The here-described tetrapod tracks are characterized by different morphologies that in most cases intergrade along the same trackway. These types of tracks, resulting from different behaviors of a single producer are known in the literature as compound traces (Sarjeant, 1979; Pickerill and Narbonne, 1995; Bertling et al., 2006; Minter et al., 2007; Buatois and Mángano, 2011). The producer making compound traces adopts different, subsequent locomotor styles resulting in distinct morphologies usually found separately (Buatois and Mángano, 2011). The typical example of a compound trace is the transition between invertebrate locomotion and resting traces (e.g. Cruziana and Rusophycus; Crimes, 1970; Mángano et al., 1996). Compound trace fossils have been classified at both the ichnogeneric and ichnospecific ranks (Pickerill and Narbonne, 1995).

In invertebrate ichnology, compound specimens are widely reported in the ichnological literature (e.g. Pickerill, 1994; Pickerill and Narbonne, 1995; Rindsberg and Martin, 2003) but the same cannot be said for vertebrate ichnology. Nevertheless, in both cases the naming of compound tracks is problematic and controversial. Most authors agree to avoid synonymization of ichnotaxon previously found separately to avoid losing information (Sarjeant, 1979; Pickerill and Narbonne, 1995; Bertling et al., 2006; Minter et al., 2007). Sarjeant (1979) stated that a name applied to a particular structure should not be applied to another structure of a dissimilar type.

Pickerill and Narbonne (1995, p. 67) reinforced this concept and suggested the use of a simple classification made by both ichnotaxon names in which the first ichnotaxon is linked to the second by "with", or "intergrading with". In this hybrid nomenclature, the predominant component (N50\%) is represented by the primary descriptor, while the secondary subsidiary element is represented by the secondary name; furthermore they considered the approach valid both at the ichnogeneric and the ichnospecies rank. Bertling et al. (2006) affirmed that intergradation of traces belonging to different ichnogenera representing distinct 

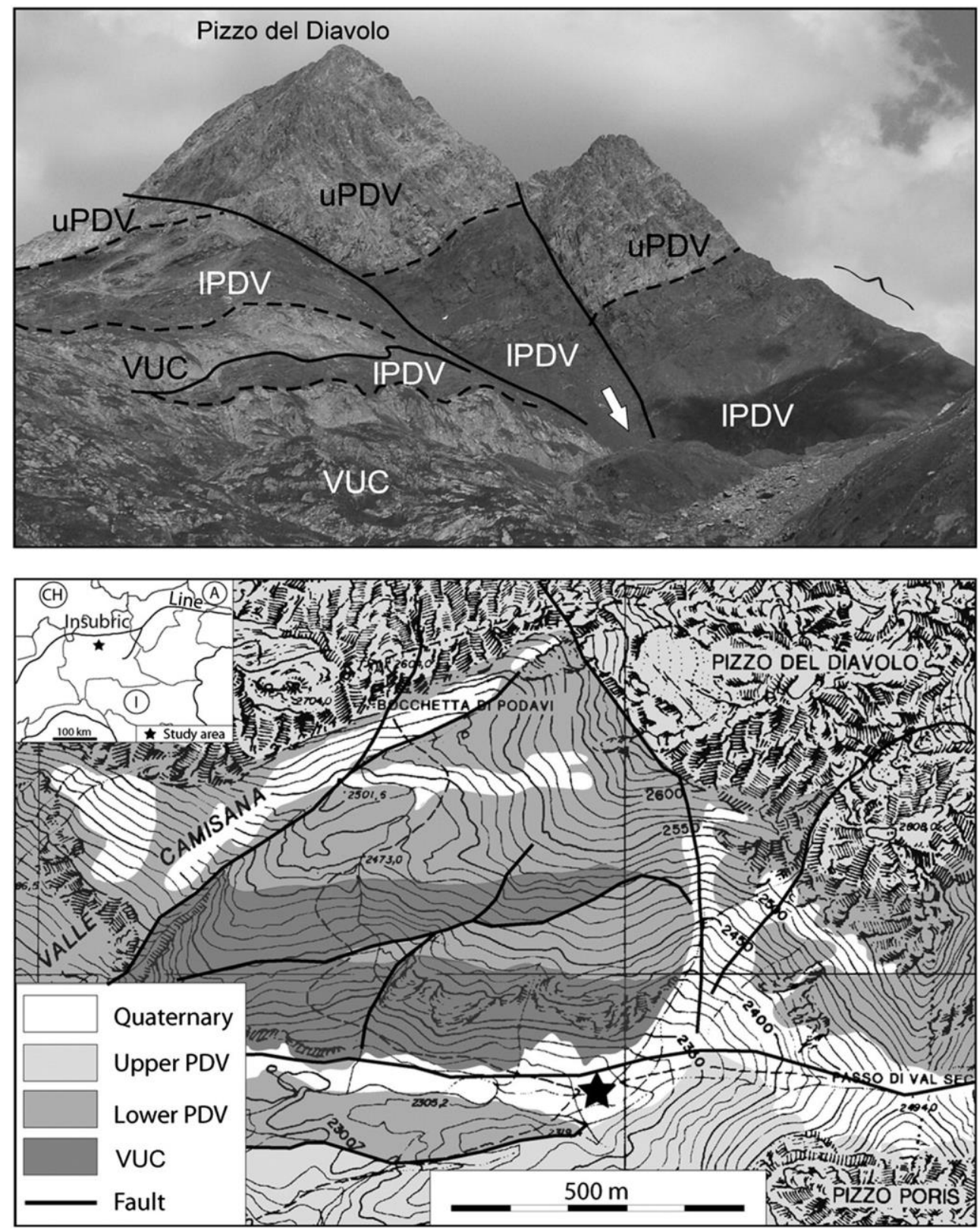

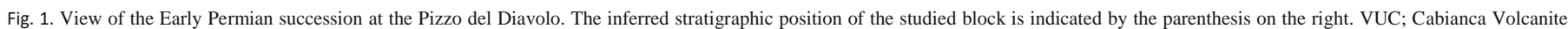

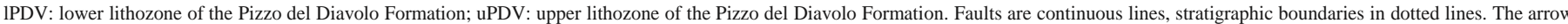
points to the position of the studied block. Below: geological map of the upper Brembo valley, with the position of the studied block (star), fallen from the northern

slope.

producer behavior would not imply synonymization; nevertheless, they suggest the adoption of a new name only when the whole compound structure represents a recurrent pattern of behavior. Minter et al. (2007) suggested that specimens demonstrating intergrading between two ichnotaxa can be used to justify synonymy only when the morphological variation between them is minor (i.e. resulting from minor behavioral or preservational variation); intergradations between different morphologies, related to major behavioral variation, such as feeding traces and resting traces or walking and swimming tracks, cannot be synonymized, because a single name or additional names would lead to the loss of information. Minter et al. (2007) thus suggested to maintain the names of trace fossils that commonly occur as isolated specimens uniting them by using the multiplication " $x$ " symbol (e.g. Cruziana $x$ Rusophycus). 
We agree with previous authors that synonymization should be avoided and with Minter et al.'s (2007) (and, previously with Pickerill and Narbonne, 1995) suggestion of indicating both names. However, we consider the use of the multiplication symbol contrary to the rules of the international codes on nomenclature (International Commission on Zoological Nomenclature, 1999; Brickell et al., 2009; McNeill et al., 2012). The " $x$ " symbol, as acknowledged by Minter et al. (2007), is already used to indicate a hybrid (e.g. Agrostis $\times$ Polypogon) as formalized in the International Code of Nomenclature for algae, fungi, and plants (McNeill et al., 2012). We acknowledge that Minter et al. (2007) used this symbol to avoid proposing a new one, however this contrasts with the aim of the nomenclature codes, which are meant to formalize univocal and unequivocal names, terms and symbols in biology. Experts of other fields aside from ichnology might erroneously interpret the " $x$ " symbol as used to indicate hybrids vs. compound traces, and botanists could even be misled in their research. For the description of compound traces is therefore proposed the use of both (two, or more) names of the trace fossils that may be found isolated, but indicating their relation by connecting them with the symbol " $\mathrm{C}$ ", standing for "Compound trace" (e.g. Batrachichnus C Lunichnium). To our best knowledge, this formula has never been used in previous official nomenclatural acts and is therefore available, unique and unequivocal. Other more intuitive symbols, such as the " + " are in use in graft-chimera names (e.g. Crataegus + Mespilus) for cultivated plants (Brickell et al., 2009).

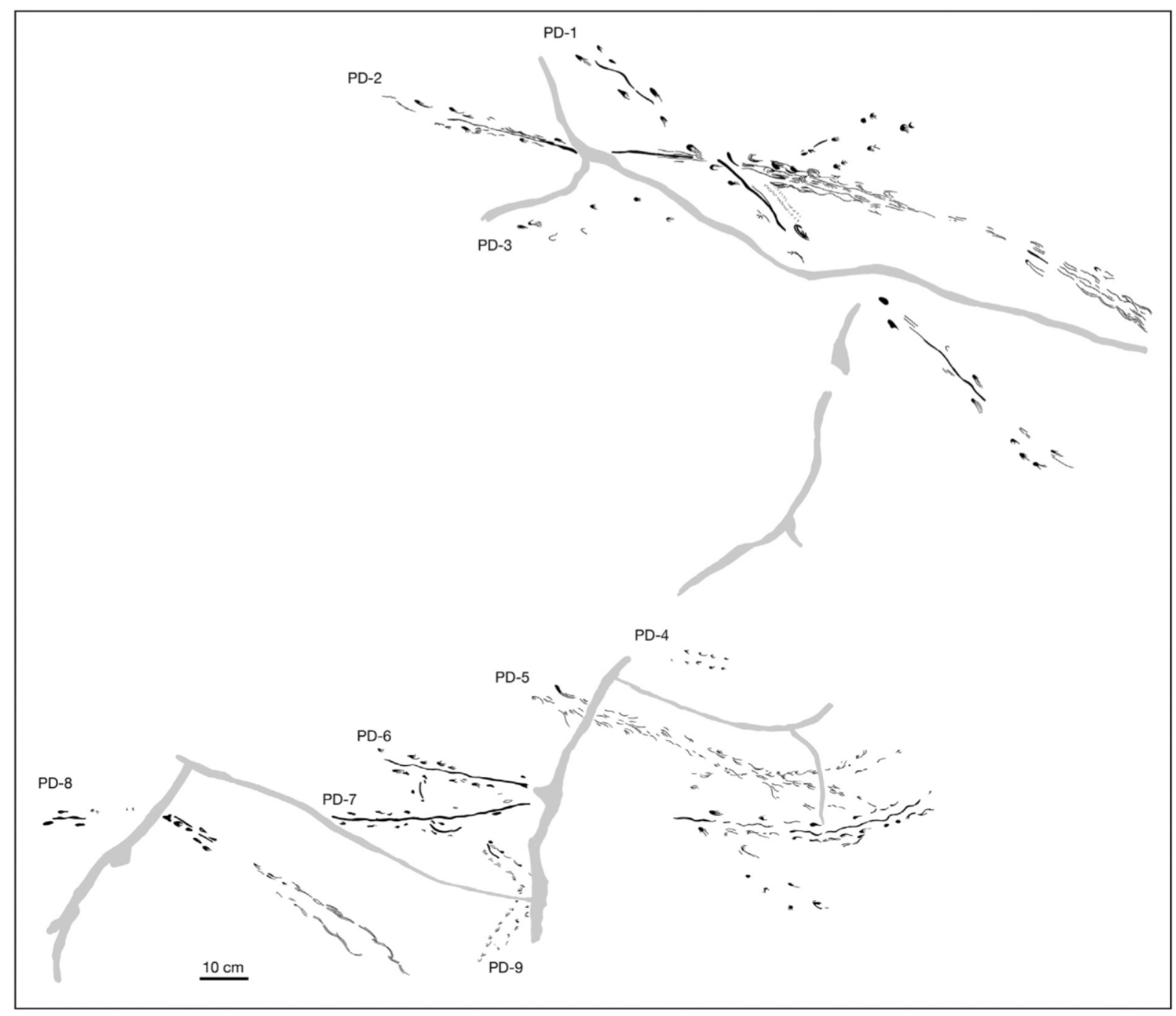

Fig. 2. Overview of the studied track-bearing surface, outlining the nine tetrapod trackways.

\section{Systematic paleontology}

Ichnogenera Batrachichnus Woodworth, 1900 C Lunichnium Walter, 1983

Type ichnospecies. Batrachichnus salamandroides (Geinitz, 1861); Lunichnium rotterodium Walter, 1983. Figs. 2, 3, 4, 5, 6, 7, 8. 


\subsection{Referred material}

The described material occurs on a surface of an erratic boulder found at the foot of the south-western side of the Pizzo del Diavolo Mt. (Orobic Alps, Lombardy, N Italy). The track-bearing surface was photographically reproduced and traced on acetate layer. The original drawing is housed at the MUSE - Museo delle Scienze, Trento (I). Main parameters of tracks and trackways are shown in Table 1.

\subsection{Description}

Tracks of quadrupedal tetrapods with tetradactyl manus and pentadactyl pes with short and blunt digits. Pes is slightly larger than manus (Fig. 4A).

Manual imprints are plantigrade and exhibit four slender digit traces with an increase in digit length from I to III; digit IV is about as long as or slightly shorter than II. Digit group I-III is separated from digit IV that diverges outward (Fig. 4A). Digits I-III could be distally bent inward, while digit IV is outward oriented. The total divergence of digits is $85^{\circ}$. Manus can show elongated digit marks or curved digit scratches.

Pedal imprints are clearly plantigrade and when complete show five short digit traces (Fig. 4A). The proximal margin, when preserved, is broad. In some tracks only four digits and a broad sole pad are preserved. Digits II-IV are grouped, with digit IV probably the longest or as long as digit III. Digit V is placed somewhat posteriorly and laterally. The total divergence when digits are splayed is $45^{\circ}$.

Manual and pedal prints are equidistant from the midline of the trackway. Manual prints are usually anterior to pedal prints. Manus-pes distance is constant through the whole length of the trackway. Manus and pes prints point forward. In some cases both manual and pedal imprints have their long axis and the elongated digit traces pointed inwardly on the left side and outwardly on the right side.
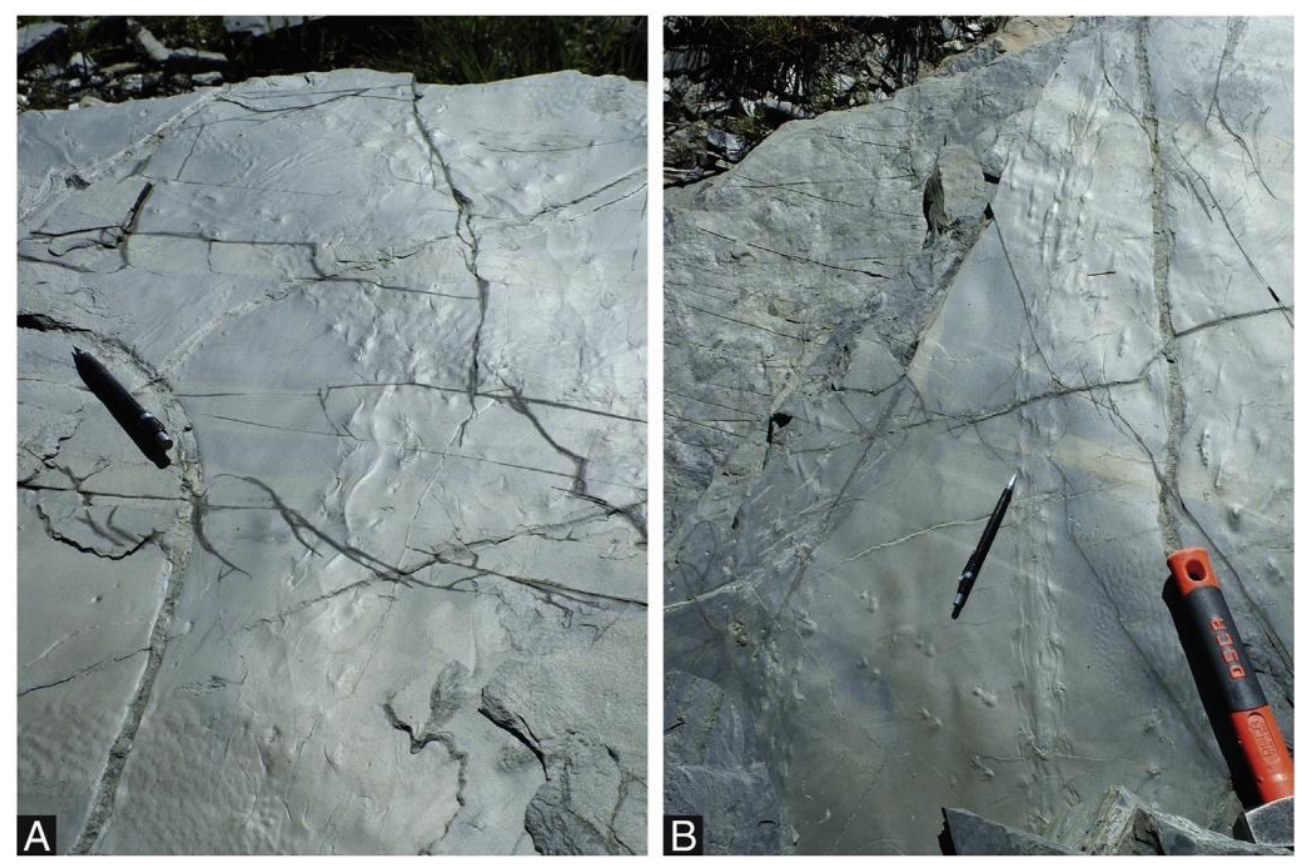

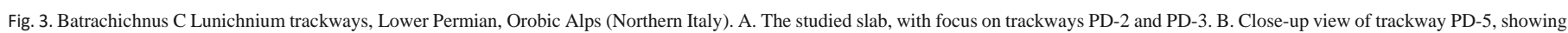
irregular and curved digit scratches on either side of the trackway. A clear tail drag occurs along the midline.

The studied trackways display several extramorphological variants. Both fore and hind limb tracks can show few anatomical details, essentially represented by elongated digit marks, somewhat outwardly 

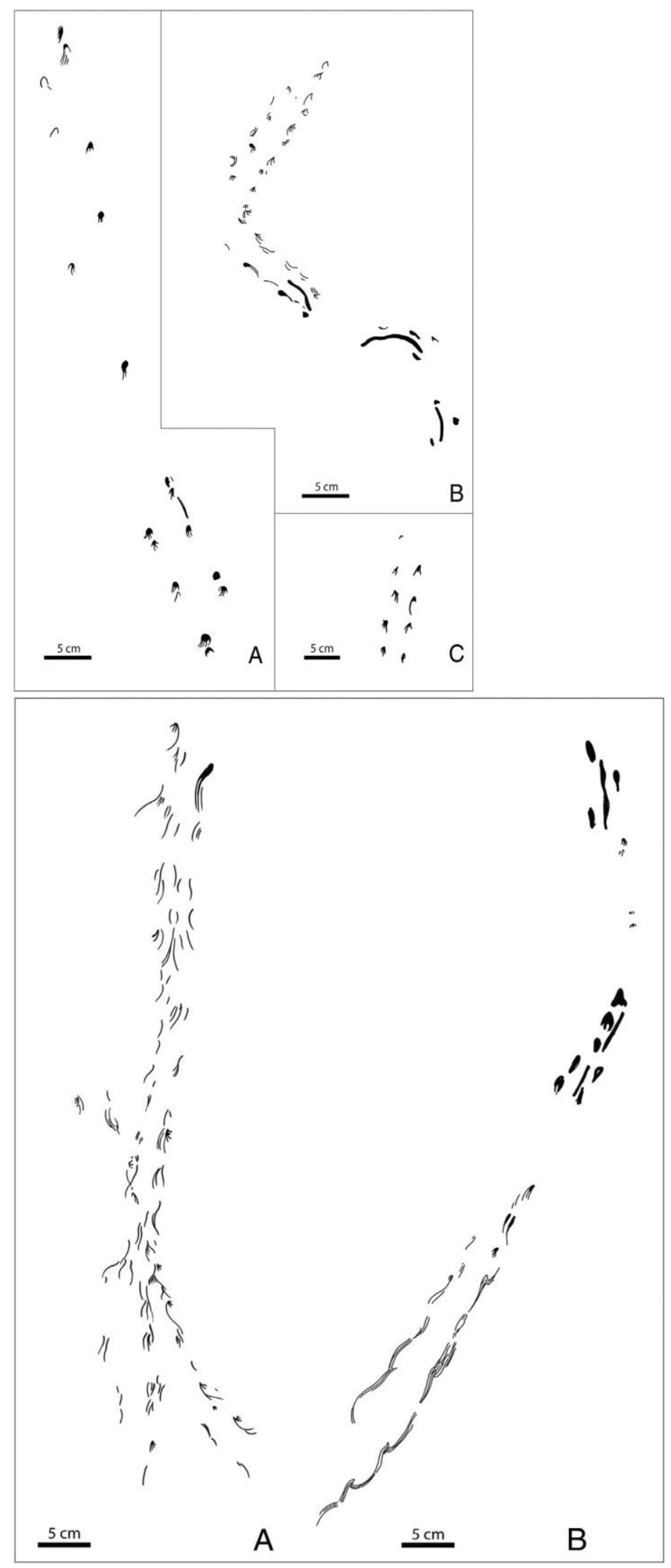

Fig. 4. Sketches of the trackways PD-3 (A), PD-9 (B) and PD-4 (C), preserving anatomical details of both fore and hind limbs. Fig. 5. Sketches of the trackways PD-5 (A) and PD-8 (B). Footprints and tail drags are substituted by curved digit marks and parallel scratches drawing discontinuous arcs. 


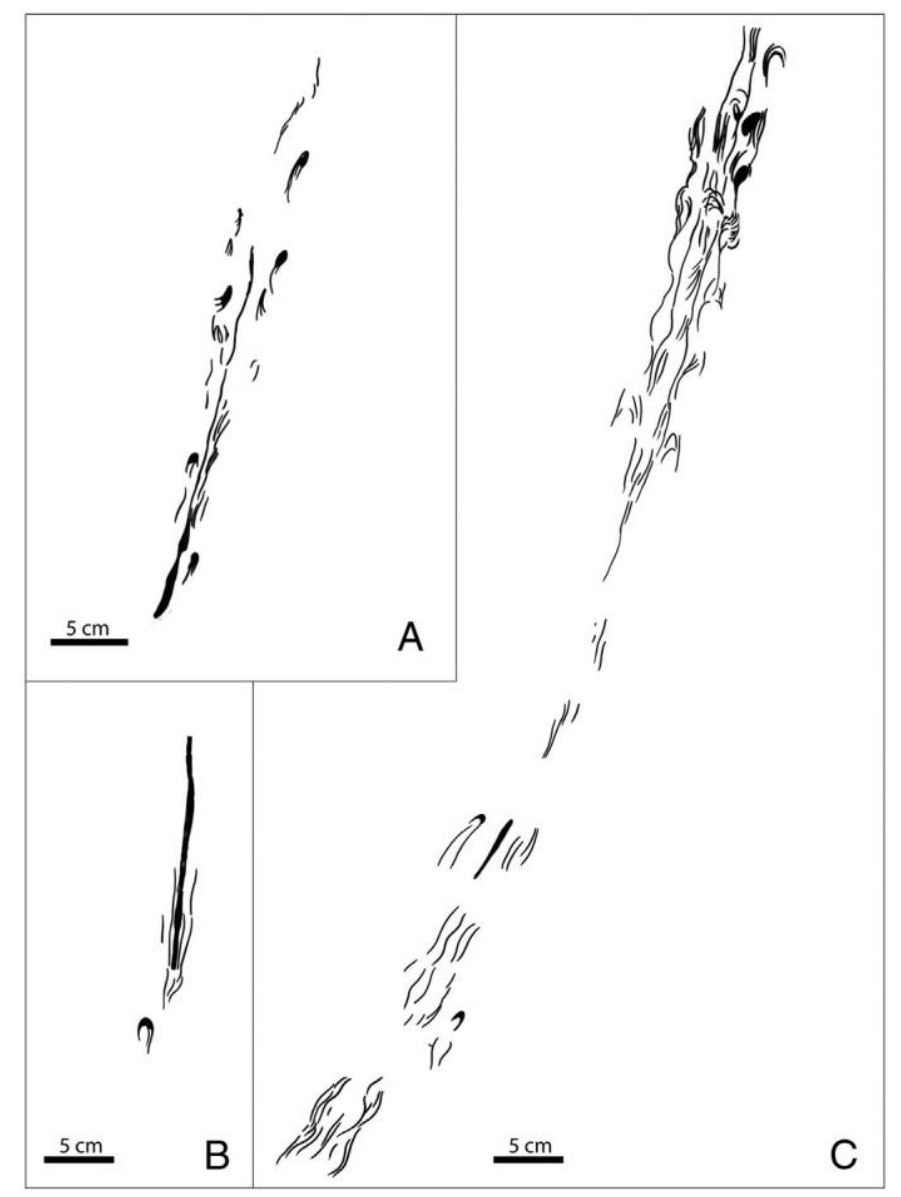

Fig. 6. Sketches of the trackway PD-2, subdivided into three portions (A, B, C), showing a sequence indicative of an increasing water-content of the trampled surface.

oriented, with the sole pad rarely or not preserved (Figs. 4B, 5, 6). The manual imprint, when visible, is represented by paired and outwardly curved digit traces and its morphology strongly varies, displaying paired and curved outward digit traces, grossly pearshaped, wider at its base and tapering or bifurcating distally into two-toed scratch marks curved outwards.

The pedal imprints of most of the trackways consist entirely of digit impression, revealing two, three or four parallel and elongated digit marks, curved outward (Figs. 4B, 5A, C). Digit lengths decrease from internal to external digits. The heel may be narrow or elongated and anteriorly bi-, tri- or quadrifurcate into sub-parallel and outwardly curved elongated digit scratches (Figs. $5 \mathrm{~A}, 6 \mathrm{~A}, 7 \mathrm{~B})$.

Manus and pes couples sometimes cannot be easily distinguished. Tracks display different morphologies varying from subelliptical to pear-shaped; they are elongated, wider proximally with blunt or elongated digit traces (Figs. 4B, 5B, 7A, B, C).

Trackways may show a progressively wider gauge, with tracks only represented by discrete curvilinear imprints, with two-three elongated and parallel digit grooves that draw discontinuous arcs with alternate symmetry on the two opposite sides (Fig. 5B).

Continuous to discontinuous body or tail drag may occur along the midline (width $=0.40-0.70 \mathrm{~cm}$ ). It is represented by a narrow straight to slightly sinuous medial impression, essentially made of single or paired scratch marks (Figs. 4B, 5A, B, 6A-C, 7A-C).

\subsection{Remarks}

The best-preserved manual tracks exhibit four digital impressions (PD-3 Fig. 4A). Batrachichnus Woodworth, 1900 and Limnopus Marsh, 1894 (Haubold, 1996) are Early Permian ichnogenera with a four-toed manus, with evident separation between digit group I-III and digit IV (Haubold et al., 1995). Batrachichnus is characterized by pace angulation of $80^{\circ}-90^{\circ}$ that could exceed $100^{\circ}$ and $110^{\circ}$ for the 


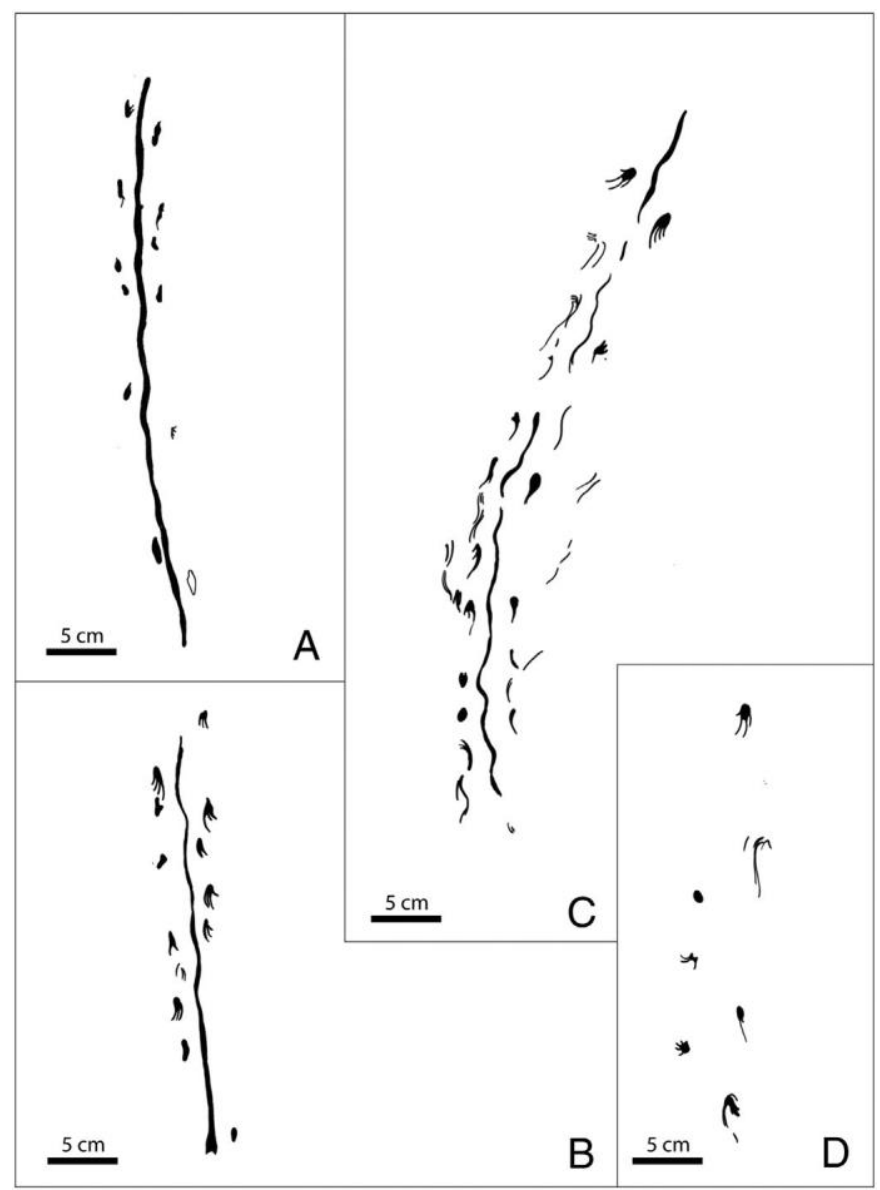

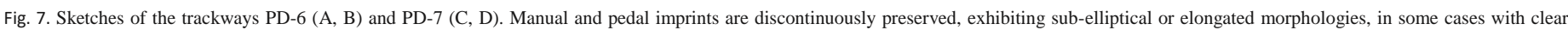
anatomical details (digit traces). The tail drag is nearly continuous and sinuous.

pes while in Limnopus it ranges from $70^{\circ}$ to $96^{\circ}$ (Haubold, 1970, 1971; Haubold et al., 1995). In these ichnogenera, pes length usually ranges from 20 to $40 \mathrm{~mm}$ (Haubold et al., 1995), but in Limnopus can be up to $135 \mathrm{~mm}$ (Tucker and Smith, 2004). In Limnopus, the pedal imprint is usually positioned close behind the manual imprint and both manual and pedal imprints are generally short and rounded distally. 
Some authors (e.g. Voigt et al., 2011) have considered the two ichnogenera as end-members of a continuous morphological spectrum (named Plexus Batrachichnus - Limnopus), thus questioning the status of the morphs as separate ichnotaxa. Tucker and Smith (2004) proposed that Batrachichnus should be reduced to subgeneric rank within Limnopus. This proposal was recently rejected by Lucas et al. (2011), who continue to consider Batrachichnus and Limnopus as separate ichnogenera. Batrachichnus salamandroides (Geinitz, 1861) is a common ichnospecies in the Lower Permian deposits of the Orobic and Trompia basins (Conti et al., 1997; Santi and Krieger, 2001); it was recently noted also in the Tregiovo basin (Avanzini et al., 2008). If compared with the tracks from the Lower Permian of the Orobic basin, assigned by Santi and Krieger (2001) to B. salamandroides, only a gross similarity in the trackway pattern and parameters can be appreciated, those being badly preserved and incomplete. Some characters recognized in the footprints of studied trackways (PD-1, PD-6, PD-7) match those figured and described by Haubold et al. (1995, Fig. 6, NMMNH P-23298) and Hunt et al. (1995, Fig. 2E, NMMNH P-23277) from the Hueco Formation (Robledo Mountains, New Mexico). They were ascribed to Batrachichnus delicatulus (Lull, 1918) considered by many authors equivalent to B. salamandroides (e.g. Lucas et al., 2005, 2011). The tracks from the Robledo Mountains are often coupled with a sinuous tail drag, lack clear anatomical details but display concave outwardly curved scratches.

All the trackways display different morphologies likely related to physical properties of the substrate and to the locomotor behavior of the producer. Some trackways from the Pizzo del Diavolo Formation are characterized by discrete to continuous, curved imprints; they are wider posteriorly and can bifurcate anteriorly with alternate symmetry. These characters are typically observed in the
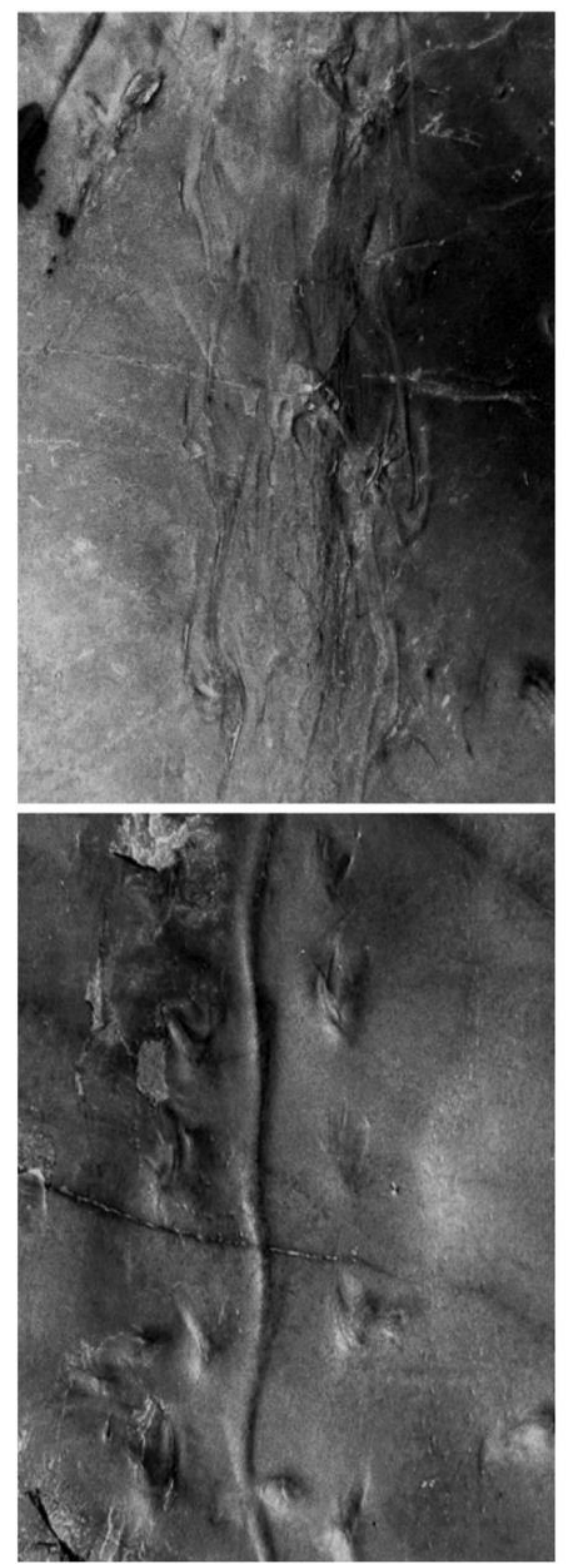

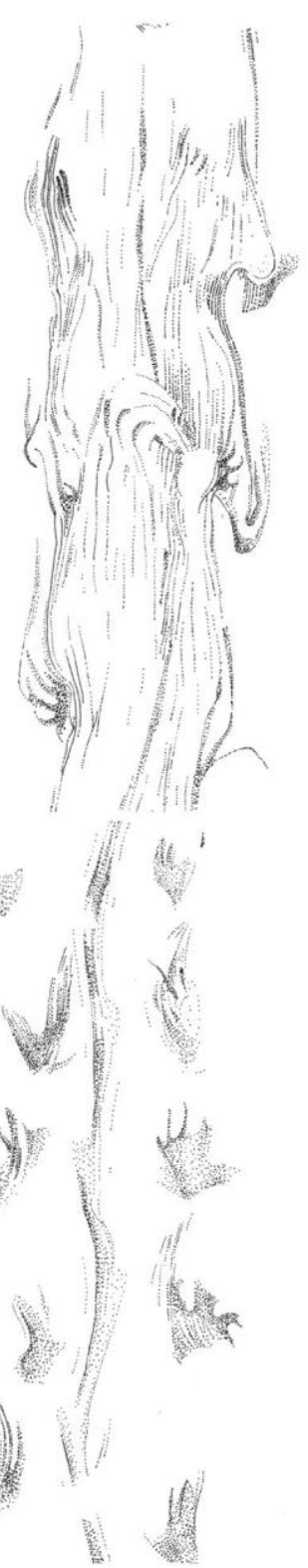

A

B 
ichnogenus Lunichnium, erected by Walter (1983) on Lower Permian material of south-east Germany. Lunichnium rotterodium Walter, 1983 (p. 166, pl. 8, Fig. 7; pl. 9, Fig. 1) consists of paired sets of curved elements, concave outwards that bifurcate and alternate on either side of the trackway. Walter (1983) interpreted Lunichnium as an arthropod swimming trackway. Turek (1989), on the basis of specimens from the Upper Carboniferous of the western Czech Republic, reinterpreted Lunichnium as a swimming trace of a temnospondyl amphibian and distinguished two different morphotypes that may intergrade gradually one into another: i) Type A, made of a continuous and sinuous trackway bounded by a pair of sinusoidal grooves, that can bifurcate in alternate segments of the trackway; ii) Type B, consisting of discontinuous S-shaped prints that bifurcate and reconverge, forming an acute angle with the trackway midline. Turek (1989) also erected two new ichnospecies: Lunichnium gracile (Pls. 74 and 75 and Figs. 6 and 8) and Lunichnium anceps (Fig. 7B,C). Lunichnium gracile is characterized by narrow trackways (width $4-5 \mathrm{~mm}$ ) interrupted by resting traces with impressions of limbs or of the whole body. Lunichnium anceps is characterized by a wider trace (width 10-14 mm), and also preserve different impressions of feet along the discontinuous trackway ("Type B" sensu Turek, 1989). Keighley and Pickerill (1997) questioned the two new ichnospecies of Turek (1989) and proposed to synonymize them with Undichna bina Anderson, 1976, a fish-swimming fossil trail. Minter and Braddy (2006), in their revision of the ichnospecies L. rotterodium, rejected this interpretation, being both L. gracile and L. anceps clearly different from U. bina for the presence of limb and body impressions along the trackway. Nevertheless Minter and Braddy (2006) considered the ichnospecies L. gracile and L. anceps as end members of a continuum and suggested to synonymize them with L. rotterodium, that can thus form continuous and sinuous trackways with associated manual, pedal

Table 1

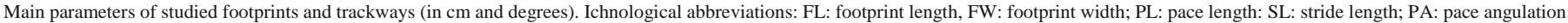
TL: trackway length. TW: trackway width.

\begin{tabular}{|c|c|c|c|c|c|c|c|c|}
\hline & Couples & Manus FL & Manus FW & & Manus PL & & Manus SL & Manus PA \\
\hline PD-1 & - & 3.30 & 0.80 & & - & & - & $98^{\circ}$ \\
\hline PD-2 & - & 1.85 & 0.92 & & - & & - & - \\
\hline PD-3 & 6 & 1.30 & 1.10 & & $7.40-8.50$ & & $7.60-9.60$ & $80^{\circ}$ \\
\hline PD-4 & 8 & 1.10 & 0.74 & & 3.33 & & $5.10-5.50$ & $100^{\circ}-104^{\circ}$ \\
\hline PD-5 & - & - & - & & - & & - & - \\
\hline PD-6 & 5 & $1.48-1.60$ & 0.74 & & $7.40-8.50$ & & $7.60-9.60$ & $80^{\circ}$ \\
\hline PD-7 & - & - & - & & - & & - & - \\
\hline PD-8 & - & - & - & & - & & - & - \\
\hline \multirow[t]{2}{*}{ PD-9 } & - & 0.74 & 0.55 & & - & & $4.00-5.00$ & $70^{\circ}$ \\
\hline & $\begin{array}{l}\text { Pes FL } \\
(\mathrm{cm})\end{array}$ & $\begin{array}{l}\text { Pes FW } \\
(\mathrm{cm})\end{array}$ & $\begin{array}{l}\text { Pes PL } \\
(\mathrm{cm})\end{array}$ & $\begin{array}{l}\text { Pes SL } \\
(\mathrm{cm})\end{array}$ & & $\begin{array}{l}\text { Pes PA } \\
\left({ }^{\circ}\right)\end{array}$ & $\mathrm{TL}$ & TW \\
\hline PD-1 & $3.33-4.07$ & $1.10-1.30$ & - & - & & $95^{\circ}-114^{\circ}$ & 130 & $4.40-5.50$ \\
\hline PD-2 & 4.00 & 0.90 & - & - & & $79^{\circ}-84^{\circ}$ & 170 & $3.70-5.20$ \\
\hline PD-3 & 1.48 & 1.30 & $5.50-8.10$ & $7.00-8.10$ & & $64^{\circ}-76^{\circ}$ & 90 & $4.80-7.40$ \\
\hline PD-4 & 1.29 & 0.48 & 3.33 & $4.80-5.10$ & & $100^{\circ}$ & 9.25 & 3.00 \\
\hline PD-5 & - & - & - & - & & - & 82,5 & $4.0-5.0$ \\
\hline PD-6 & 1.48 & 1.30 & $5.50-8.10$ & $7.00-8.00$ & & $79^{\circ}-81^{\circ}$ & 125 & - \\
\hline PD-7 & 2.9 & 1.10 & - & - & & $77^{\circ}-79^{\circ}$ & 120 & $4.00-4.80$ \\
\hline PD-8 & - & - & - & - & & $65^{\circ}-100^{\circ}$ & 80 & $3.33-5.96$ \\
\hline PD-9 & 1.10 & 0.50 & $3.70-4.40$ & - & & $60^{\circ}-86^{\circ}$ & 30 & $3.00-3.40$ \\
\hline
\end{tabular}


or body impressions. The trackway of L. rotterodium can also preserve a slightly sinuous medial impression, as testified by the specimens from the Lower Permian of New Mexico (Fig. 5 of Minter and Braddy, 2006).

Minter and Braddy (2006) proposed also a new combination Lunichnium westerbengensis (Schweigert, 2001) for Undichna westbergensis, originally attributed by Schweigert to a "crossopterygian"fish. In their proposal they considered the pattern of paired prints with alternate symmetry more similar to Lunichnium than to Undichna, and maintained L. westerbergensis distinct from L. rotterodium for its larger width (about $100 \mathrm{~mm}$ ).

Trackways PD-5 (Fig. 5A) and PD-9 (Fig. 4B) show some striking similarities, respectively with the specimens assigned to Lunichnium westerbergensis Schweigert (2001) and Lunichnium anceps Turek, 1989. Trackway PD-5 comprises sets of discrete, discontinuous and parallel tracks, concave outwards and with alternate symmetry; PD-9 is characterized, especially in its last portion, by discontinuous and alternate S-shaped grooves.

The proximal portion of trackway PD-2 (Fig. 6A) closely resembles the trackway assigned to Lunichnium rotterodium from the Lower Permian of New Mexico (specimen NMMNH P4000; Fig. 5 of Minter and Braddy, 2006). The pedal imprint shows an elongate heel trace and it anteriorly bi-, tri- or quadrifurcate into subparallel and outwardly curved elongated digit traces. The smaller manual imprint also curves concavely outwards and can show digit traces. A slightly sinuous medial impression occurs along this portion of the trackway.

Finally the trackway PD-8 (Fig. 5B) show a clear example of how Batrachichnus could intergrade into Lunichnium along the same trackway. In the first portion manual and pedal imprints are testified by narrow and sub-elliptical ichnites and a continuous slightly sinuous medial impression occur along the trackway. In the second portion tracks display different morphologies varying from sub-elliptical to pyriform with blunt or elongated digit traces and a fairly straight medial impression. At the beginning of the third portion, pes and manus tracks display clear elongated digit marks, slightly curved outward. The last portion of the trackway PD-8 shows a progressively wider gauge. Tracks are represented only by two-three elongated and parallel digit grooves that draw discontinuous arcs and have alternate symmetry.

The described tracks, therefore, show a variety of morphs ranging from Batrachichnus to Lunichnium both in individual tracks and along a single trackway. Lunichnium is similar to Batrachichnus even if Batrachicnus shows clear and distinct pes-manus couples, while Lunichnium is mainly represented by continuous to discontinuous digit traces. According to Minter and Braddy (2006), Lunichnium could be regarded as an extramorphological variant of Batrachichnus, and interpreted as an amphibian swimming trace. Here is thus provided support to the existence of a Batrachichnus-Lunichnium continuum intergrading from one to another along the same trackway and documenting the transition from walking, to submerged-walking and swimming.

\section{Identification of the trackmaker}

Footprint length (FL) and gleno-acetabular distance (GAD) have been used as proxies for extrapolating the body length of the producer. Given an average FL of b2 cm, and a GAD of $5.5 \mathrm{~cm}$, the total length of the producer must have been less than $10 \mathrm{~cm}$.

Possible producers of the Pizzo del Diavolo trackways are conservatively non-amniote tetrapods, among them, small amphibians and reptiliomorphs (embolomeres). During the Early Permian, amphibians were represented by temnospondyls and lepospondyls (microsaurs and nectrideans). The number of digits of the manus excludes reptiliomorphs (embolomeres) and nectrideans as possible candidates because both have five digits in the manus (Carroll, 1987; Bossy and Milner, 1998). The attribution is thus limited to small or juvenile temnospondyls and small salamander- to lizard-like microsaurs, both characterized by four manual digits (for a complete discussion see also Haubold, 1970, 1971; Hunt et al., 1995; Haubold, 1996, 2000; Braddy et al., 2003; Voigt et al., 2011).

Among known Early Permian temnospondyls miniaturization occurred in branchiosaurids and amphibamids (both Dissorophidea), primarily known in central and southern Europe from the Germanic basin (Werneburg and Schneider, 2006; Anderson et al., 2008) and Sardinia (Werneburg et al., 2007).

The microsaurs, the largest group of lepospondyls known from Carboniferous and Early Permian localities of Europe and North America, were mainly terrestrial in habits (Carroll and Gaskill, 1978).

\section{Analysis of locomotion}

To interpret and determine locomotion dynamics in the studied trackways, we used a survey of locomotor performance across a range of urodelan amphibians. Comparison has been made also by slow motion analysis of two published videos (see Section 3. Material and methods). Salamanders have been chosen since they are the closest postural model for early tetrapods among extant taxa (Schaeffer, 1941; Edwards, 1977, 1989; Ashley-Ross and Bechtel, 2004; Ijspeert et al., 2007; Ashley-Ross et al., 2009).

When tracks are impressed on a faintly wet substrate, as in trackways PD-3, PD-4, and PD-9, anatomical details of both manus and pes are thoroughly preserved (Figs. $4 \mathrm{~A}-\mathrm{C}$ ). In this condition the amphibian walked using a stepping gait, in which diagonally 
opposed limbs are moved together like present-day salamanders (Ashley-Ross and Bechtel, 2004; Ashley-Ross et al., 2009). Other trackways, impressed on wetter substrates, show a variety of extramorphologies, such as digit elongations and sinusoidal digit scratches. In trackways PD-1, PD-2, PD-5, PD-6 the elongated toe marks that curve concavely outward probably result from the toes dragging when the knee/elbow is flexing and the foot is lifted to go into the swing phase of the stride (Figs. 2, 5A, 7A-C). This type of track has been produced during terrestrial walking on a water-saturated substrate (see Brand, 1996 for a comparison). The sinuous scratches on the medial portion of trackway PD-2 are thus probably due to dragging of the tail or underside of the body.

Although trackways PD-1, PD-2, PD-5, PD-6, and PD-7 show sequences indicative of more water-saturated conditions, trackway PD-8 shows a unique pattern. This trackway exhibits a transition between distinct, plantigrade tracks (i.e. footfalls) with tail drag mark, to elongated and curved toe marks and sigmoidal digit scratches without tail mark. In our interpretation, at the beginning of trackway PD-8, the small amphibian is walking on a muddy substrate but, along the trackway, it moves toward shallow water (Fig. 5B). While entering the water, the body is progressively buoyed up, as testified by the absence of tail mark and clear tracks (i.e. footfalls). During this transition, locomotor mechanics, especially for the hind limbs, changes. Analysis of Pleurodeles waltlii moving from ramp into water and from water to ramp (Ijspeert et al., 2007, supplemental material) shows that extant salamanders perform a behavior similar to that deduced from the trackways (Figs. 8, 9). When walking on land, at the beginning of the step cycle (i.e. the kick-off phase sensu Thulborn and Wade, 1989) the hind limbs are directly dragged toward the front. On the contrary, when Pleurodeles walks into the water (Fig. 9), during the kick-off phase, the hind-limbs are firstly adducted and drawn toward the rear and then toward the front, leading to two arcs: the toes draw firstly a narrow arc with the concave side facing outward and then are lifted to go into the swing phase, drawing an arc with the concave side facing toward the midline. In the first phase, the feet rotate counterclockwise in the case of the left hind limb and then slip backward and inward. This movement is probably triggered by the initial undulation of the body when the animal effectively begins to move into water and perfectly matches the features observed in the studied trackways (Figs. 7, 8). During the cycle, the toes of the fore limbs possibly touched the substrate, slipping backward as the limbs are drawn toward the rear but these scratches were then probably obliterated by the marks left by the hind limbs. The very last portion of the trackway likely record the animal's attempts to continue to walk in the deepening water; due to the buoyant support of the water, it was unable to reach the substrate with more than the toes, which slip and are drawn backward through the soft muddy surface in a shallow arc pattern as the humerus and femur are retracted. The scratch marks end when the animal finally loses purchase completely and begins to swim, possibly with the limbs held back against the body as seen in extant urodelans (Ashley-Ross and Bechtel, 2004; Ijspeert et al., 2007; Ashley-Ross et al., 2009).

The here proposed interpretation of the transition between the stance and recovery phases differs from that of Minter and Braddy (2006): in interpreting an amphibian swimming trace assigned to Lunichnium rotterodium (NMMNH P4000), the elongated digit marks that curve concavely outward were interpreted as having been produced during the period of suspension as the animal drifted forwards during the pause before the recovery phase. This implies that the limbs where held downward and passively scratched the surface. Extant salamanders show that active movements characterize the transition 

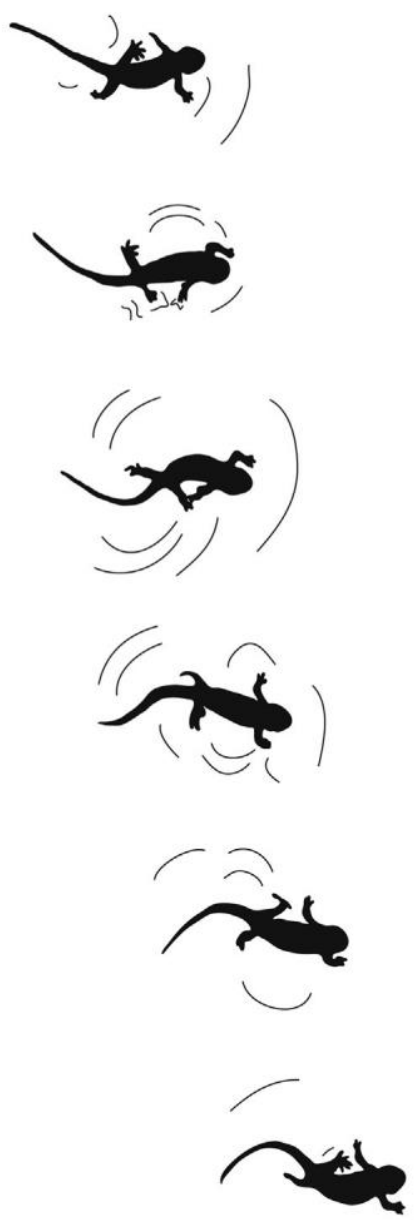

A
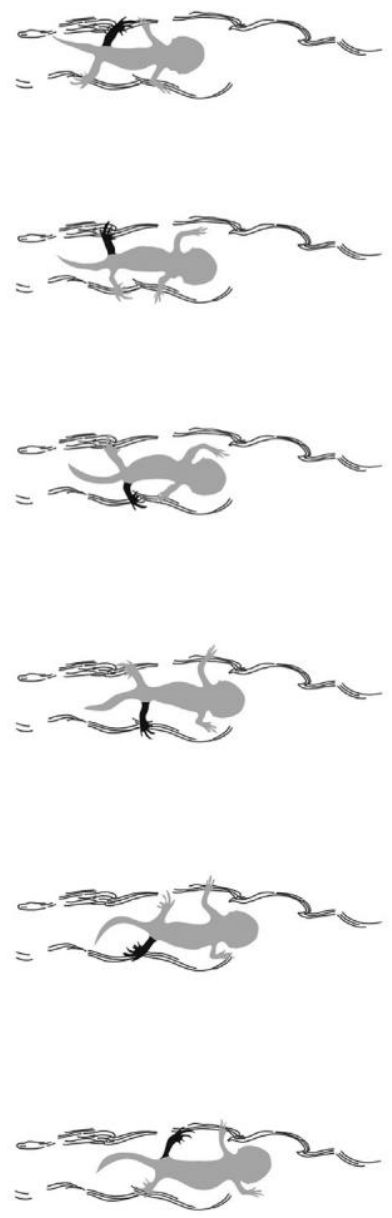

B

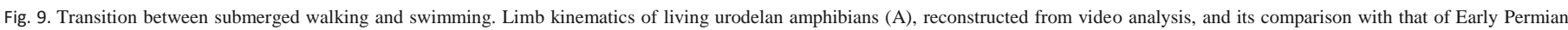
amphibians (B), deduced from the trackway PD-8. The resting hind limb is highlighted with the black color.

between the two phases and no pause exists (Ashley-Ross and Bechtel, 2004; Ijspeert et al., 2007; Ashley-Ross et al., 2009).

Turek (1989) described some intergrading specimens between swimming in the water and walking on a lake bottom attributed to an amphibian producer. Nevertheless the here described trackway PD-8 is probably the first unequivocal specimen documenting the full walking on land to swimming transition. Its features can thus be compared with published trackways that have been interpreted as documenting various "stages" of the transition. Braddy et al. (2003), for example, provided a bivariate plot of the pace angulation against the trackway width/ stride for 20 different specimens assigned to Batrachichnus delicatulus from the Lower Permian of the Robledo Mountains. The authors recognized a continuum of morphologies that was interpreted as a trend from walking to swimming. High pace angulation $\left(140^{\circ}\right)$ and low values of the trackway width/stride ratio $(0.35)$ were considered evidence for swimming behavior. On the other hand, pace angulation of about $65^{\circ}$ and trackway width/stride ratio of 1.1 were thought to be indicative of a walking gait. The same plot has been calculated for the heredescribed trackway PD-8 (Fig. 10). The observed trend appears to be opposite to that described by Braddy et al. (2003). Moving from terrestrial walking to submerged walking the pace angulation decreases and the trackway width/stride ratio increase. We acknowledge that different trackmakers may produce different patterns, nevertheless we highlight that our analysis differs from that performed by Braddy et al. (2003) in being based on a single, continuous trackway. 


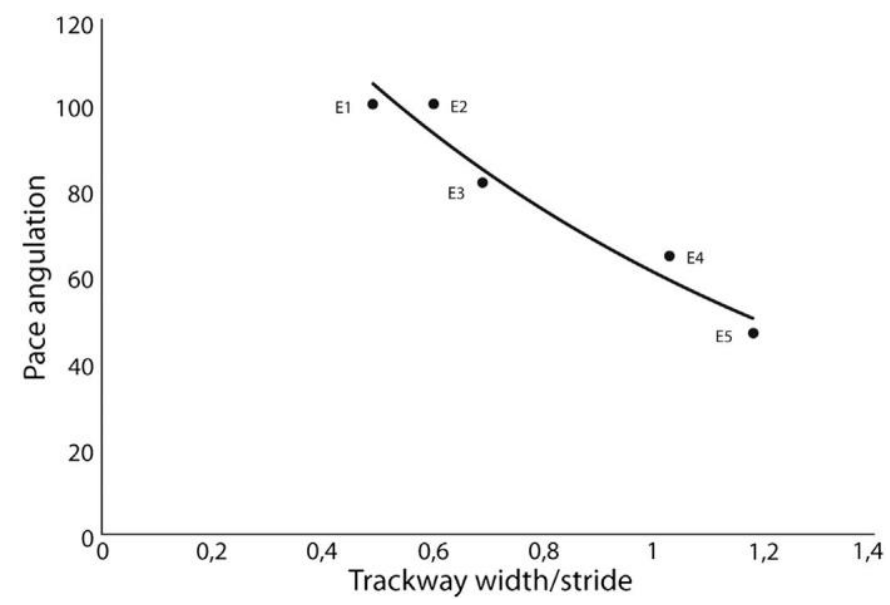

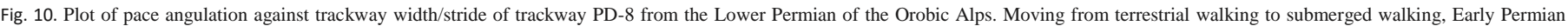
small temnospondyls-lepospondyls lowered their pace angulation and shortened the stride.

\section{Conclusion}

The Early Permian trackways from the Southern Alps provide insights into the locomotor behavior of extinct small-sized temnospondyls or salamander-like lepospondyls (microsaurs). Several extramorphologies, suggested to be behavioral and substrate-controlled, were recognized along the studied trackways. All the trackways are assigned to the compound ichnogenus Batrachichnus $\mathrm{C}$ Lunichnium, testifying to the passage from walking to swimming. The use of the connector " $\mathrm{C}$ " is proposed here as a new nomenclatural form to describe "Compound traces". Interpretation of the trackways and reconstruction of locomotor dynamics of the trackmaker was performed using filmed sequences of living urodelans moving from ramp into water. Their analysis revealed that Early Permian amphibians performed locomotor behaviors similar to those of extant salamanders. All features exhibited by the fossil trackways can be interpreted by comparison with the kinematics of their extant nearest relatives. We therefore provide evidence for conservatism of locomotor mechanics in amphibian evolution.

Trackways impressed on wet substrates preserve anatomical details of both fore and hind limbs and result from a sprawling gait, in which diagonally opposed limbs are moved together. In a terrestrial environment, during the kick-off phase, the hind limbs are directly dragged toward the front. Trackways interpreted as sequences toward more water-saturated substrates or shallow water conditions show that distinct footfalls and tail drags are substituted by curved digit marks and parallel scratches drawing discontinuous arcs. During submerged walking, hindlimb kinematics change: hindlimbs are firstly adducted and drawn toward the rear and then toward the front. This kinematic pattern is probably due to the initial undulation of body and tail when the animal effectively begins to move into water.

The here described continuous trackways show that in moving from terrestrial walking to submerged walking, Early Permian small temnospondyls lowered their pace angulation and soon began to use body and tail undulations for propulsion. This shows that the shift from walking to swimming behavior in early tetrapods, as in extant urodelan amphibians, was not a discrete change, but a complex balance between different dynamics.

\section{Authors' contributions}

F.P., M.B. and M.A. studied the specimens, analyzed the data and interpreted the results. M.A.A.-R. helped with biomechanical comparisons with extant species. F.B. and A.T. pointed out the specimens and contributed to the geology section of the paper. F.P. and M.B. wrote the paper.

\section{Acknowledgments}

We thank R. Todesco (MUSE, Trento) for her precious help in the field and A. Minelli (University of Padova) for discussion on nomenclature. Opinions expressed here are however those of the authors alone. We gratefully acknowledge the critical review by M. Benton (University of Bristol), P. Falkingham (Royal Veterinary College), N. Minter (University of Portsmouth), M. Ruta (University 
of Lincoln), S. Voigt (Urweltmuseum GEOSKOP) on an earlier version of the manuscript. Furthermore we thank the official reviewers J. Milàn (Geomuseum Faxe) and S.J. Lucas (New Mexico Museum of Natural History and Science), and the editor F. Surlyk (University of Copenhagen) for the constructive comments. This study is part of the project "The Permian-Triassic ecological crisis in the Dolomites: extinction and recovery dynamics in Terrestrial Ecosytems"financed by the Promotion of Educational Policies, University and Research Department of the Autonomous Province of Bolzano- South Tyrol.

\section{References}

Anderson, A.M., 1976. Fish trails from the Early Permian of South Africa. Palaeontology 19, 397-409.

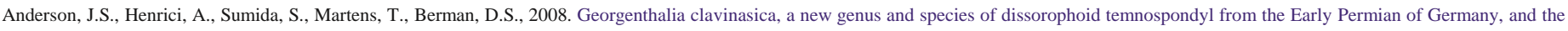
relationships of the family Amphibamidae. J. Vertebr. Paleontol. 28, 61-75.

Arduini, P., Krieger, C., Rossi, M., Santi, G., 2003. Early Permian ichnoassociation in the Scioc Valley, Orobic Basin (Lombardy, Northern Italy). Neues Jb. Geol. Paläontol. Monat. 7, $385-399$.

Ashley-Ross, M.A., Bechtel, B.F., 2004. Kinematics of the transition between aquatic and terrestrial locomotion in the newt Taricha torosa. J. Exp. Biol. $207,461-474$.

Ashley-Ross, M.A., Lundin, R., Johnson, K.L., 2009. Kinematics of level terrestrial and underwater walking in the California newt, Taricha torosa. J. Exp. Zool. 311A, 240-257.

Avanzini, M., Bargossi, G., Borsato, A., Castiglioni, G. B., Cucato, M., Morelli, C., Prosser, G., Sapelza, A., 2007. Note illustrative della Carta Geologica d’Italia alla scala 1:50.000, Foglio 026 Appiano. APAT, Dipartimento Difesa del Suolo, Servizio Geologico d'Italia, Roma, 184 pp.

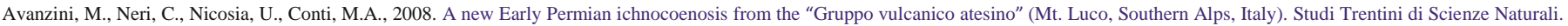
Acta Geol. 83, 231-236.

Bernardi, M., Avanzini, M., 2011. Locomotor behavior in Early Reptiles: insights from an unusual Erpetopus trackway. J. Paleontol. 85, $925-929$.

Berra, F., Felletti, F., 2011. Syndepositional tectonics recorded by soft-sediment deformation and liquefaction structures (continental Lower Permian sediments, Southern Alps, Northern Italy); stratigraphic significance. Sediment. Geol. 235, 249-263.

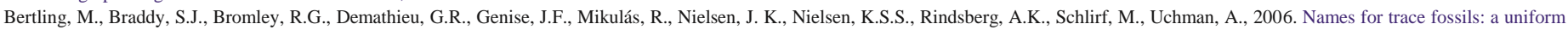
approach. Lethaia 39, 265-286.

Boriani, A., Bini, A., 2012. Note Illustrative della Carta Geologica d'Italia alla scala 1:50. 0000, foglio 56 Sondrio. ISPRA, Servizio Geologico d'Italia.

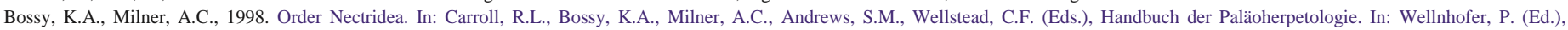
Encyclopedia of Paleoherpetology, vol. 1. Verlag Dr. Friedrich Pfeil, München, Germany, pp. 73-132.

Braddy, S.J., Morrissey, L.B., Yates, A.M., 2003. Amphibian swimming traces from the Lower Permian of southern New Mexico. Palaeontology 46, 671-683.

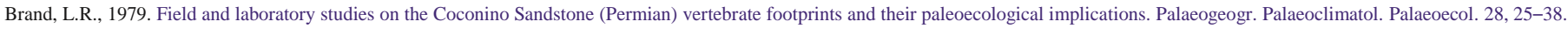

Brand, L.R., 1996. Variations in salamander trackways resulting from substrate differences. J. Paleontol. 70, 1004-1010.

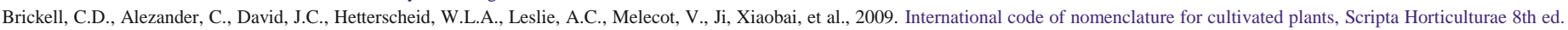
International Society of Horticultural Science, 10, pp. 1-184.

Buatois, L.A., Mángano, M.G., 2011. Ichnology-Organism-Substrate Interactions in Space and Time. Cambridge University Press, (358 pp.).

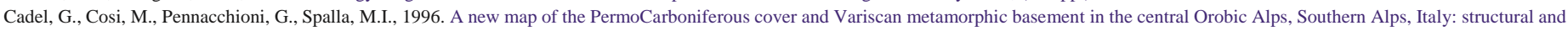
stratigraphical data. Mem. Sci. Geol. 48, 1-53.

Carroll, R.L., 1987. Vertebrate Paleontology and Evolution. W.H. Freeman, San Francisco, (698 pp.).

Carroll, R.L., Gaskill, P., 1978. The Order Microsauria. Mem. Am. Philos. Soc. 126, 1-211.

Casati, P., Gnaccolini, M., 1967. Geologia delle Alpi Orobie occidentali. Riv. Ital. Paleontol. Stratigr. 73, 25-162.

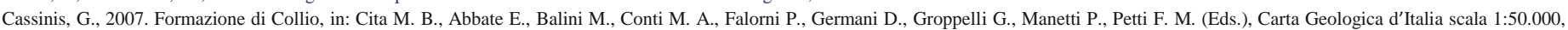
Catalogo delle Formazioni, Unità tradizionali (2). Quaderni serie III, 7, Fascicolo 7, pp. 42-45.

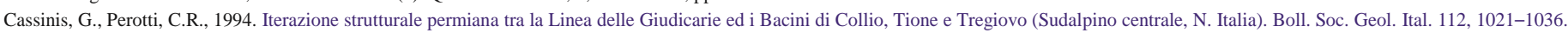
Cassinis, G., Massari, F., Neri, C., Venturini, C., 1988. The continental Permian in the Southern Alps (Italy). A review. Z. Geol. Wiss. 16, $1117-1126$.

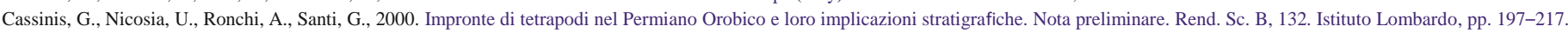

Ceoloni, P., Conti, M.A., Mariotti, N., Mietto, P., Nicosia, U., 1987. Tetrapod footprints from Collio Formation (Lombardy, Northern Italy). Sci. Geol. Mem. 39 , $213-233$.

Conti, M.A., Mariotti, N., Mietto, P., Nicosia, U., 1991. Nuove ricerche sugli icnofossili della Formazione di Collio in Val Trompia (Brescia). Natura Bresciana 26 (1989), 109-119.

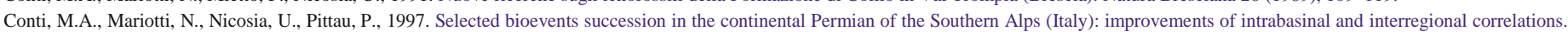

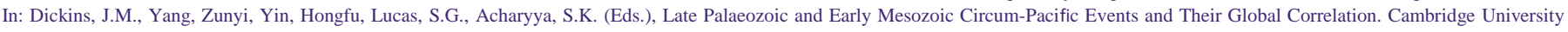
Press, pp. 51-65.

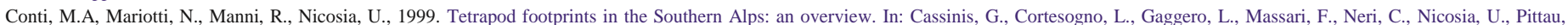

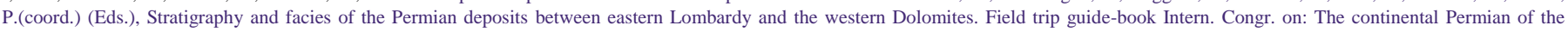
Southern Alps and Sardinia (Italy). Regional reports and general correlations", Brescia 15-25 September 1999, pp. 137-138.

Crimes, T.P., 1970. Trilobite tracks and other trace fossils from the Upper Cambrian of North Wales. Geol. J. 7, 47-68.

Curioni, G., 1870. Osservazioni geologiche sulla Val Trompia. Regio Istituto Lombardo di Scienze, Lettere, Arti, Memorie, 3, pp. 1-60.

De Sitter, L.U., De Sitter-Koomans, C.M., 1949. The Geology of the Bergamasc Alps (Lombardia, Italy). Leidse. Geol. Meded. 143, 1-257 (Leida).

Dozy, J.J., 1935. Einige Tierfärhten aus dem Unteren Perm der Bergamasker Alpen. Paläontol. Z. 17, 45-55.

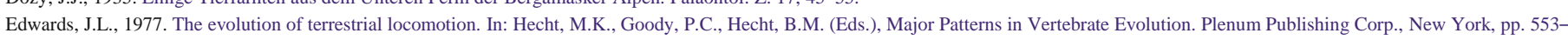
576.

Edwards, J.L., 1989. Two perspectives on the evolution of the tetrapod limb. Am. Zool. 29, 235-254.

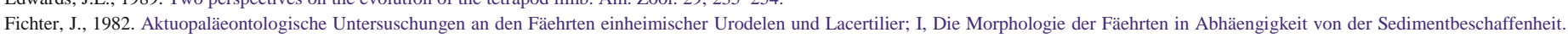
Mainz. Naturwiss. Arch. 20, 91-129.

Fichter, J., 1983. Untersuschungen an den Fäehrten einheimischer Urodelen und Lacertilier; Teil II, Aktuopalaeontologie-Quantitative Fäehrtenanalysen. Mainz. Naturwiss. Arch. 21, 25-66.

Geinitz, H.B., 1861. Dyas IWilhelm Engelmann, Leipzig, 130 pp.

Geinitz, H.B., 1869. Über Fossile Pflanzenreste aus der Dyas von Val Trompia. N. Jb. Mineral. Geol. Paläont. 1869, 456-461.

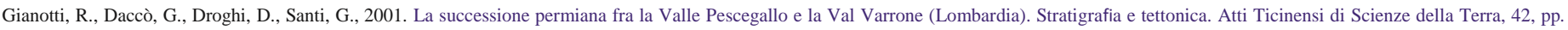
$125-140$.

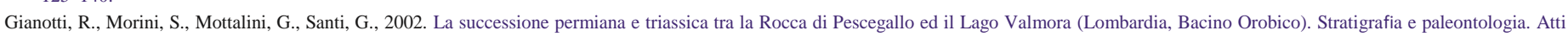
Ticinensi di Scienze della Terra, 43, pp. 55-72.

Haubold, H., 1970. Versuch der Revision der Amphibienfährten des Karbon und Perm. Freib. Forsch. C 260, 83-117.

Haubold, H., 1971. Ichnia Amphibiorum et Reptiliorum fossilium. In: Kuhn, O. (Ed.), Handbuch der Paläeoherpetologie, 18. G. Fisher-Verlag, Stuttgart, Portland, USA, pp. 1-124.

Haubold, H., 1996. Ichnotaxonomie und Klassifikation von Tetrapodenfährten aus dem Perm. Hallesches Jb. Geowiss. B 18, 23-88.

Haubold, H., 2000. Tetrapodenfährten aus dem Perm- Kenntnisstand und Progress 2000. Hallesches Jb. Geowiss. B 22, 1-16.

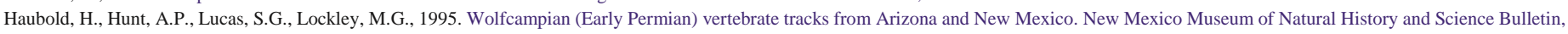
6, pp. $135-165$.

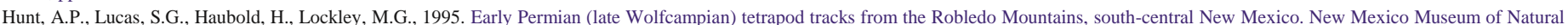
History Science Bulletin 6, 167-180.

Ijspeert, A.J., Crespi, A., Ryczko, D., Cabelguen, J.M., 2007. From swimming to walking with a salamander robot driven by a spinal cord model. Science 315, 1416-1420.

International Commission on Zoological Nomenclature, 1999. International Code of Zoological Nomenclature, 4th ed. International Trust for Zoological Nomenclature, London, (pp. 1-29 + 306). 


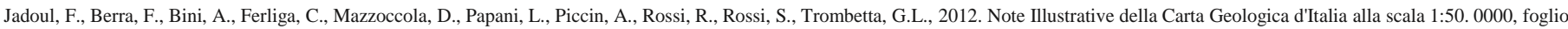
77 Clusone. ISPRA, Servizio Geologico d'Italia.

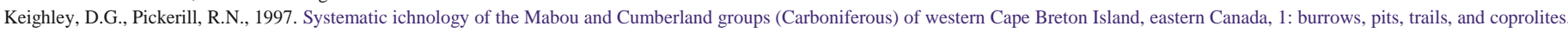
Atl. Geol. 33, 181-215.

Leonardi, G., 1987. Glossary and Manual of Tetrapod Footprint Palaeoichnology. Departamento Nacional da Producão Mineral, Brasília, (117 pp.).

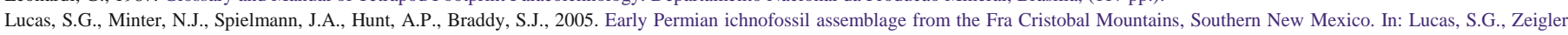
K.E., Spielmann, J.A. (Eds.), The Permian of Central New Mexico. New Mexico Museum of Natural History and Science Bulletin, 31, pp. 140-150.

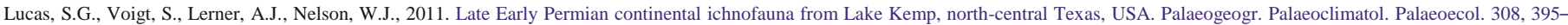
404.

Lull, R.S., 1918. Fossil footprints from the Grand Canyon of Colorado. Am. J. Sci. Ser. 4 (45), 337-346.

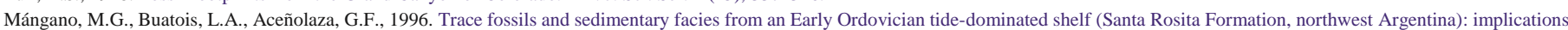
for ichnofacies models of shallow marine successions. Ichnos 5, 53-88.

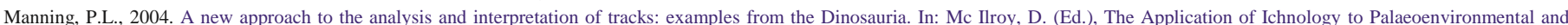
Stratigraphic Analysis. Geological Society, 228. Special Publication, London, pp. 93-123.

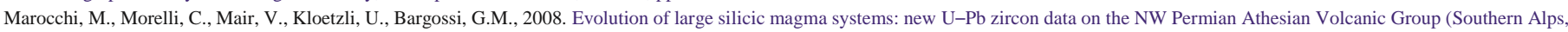
Italy). Journal of Geology Chicago University, pp. 480-498.

Marsh, O.C., 1894. Footprints of vertebrates in the Coal Measures of Kansas. Am. J. Sci. 3, 81-84.

Mckee, E.D., 1947. Experiments on the development of tracks in fine cross-bedded sand. J. Sediment. Petrol. 17, 23-28.

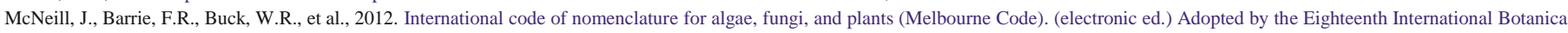
Congress Melbourne, Australia, July 2011. International Association for Plant Taxonomy, Bratislava (Retrieved 2014-3-6).

Minter, N.J., Braddy, S.J., 2006. The fish and amphibian swimming traces Undichna and Lunichnium, with examples from the Lower Permian of New Mexico, USA. Palaeontology 49, $1123-1142$.

Minter, N.J., Braddy, S.J., Davis, R.B., 2007. Between a rock and a hard place: arthropod trackways and ichnotaxonomy. Lethaia 40, 365-375.

Nicosia, U., Ronchi, A., Santi, G., 2000. Permian tetrapod footprints from W Orobic Basin (Northern Italy). Biochronological and evolutionary remarks. Geobios $33,753-768$.

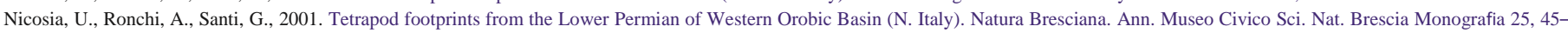
50 .

Peabody, F.E., 1959. Trackways of living and fossil salamanders. Univ. Calif. Publ. Zool. 63, 1-72.

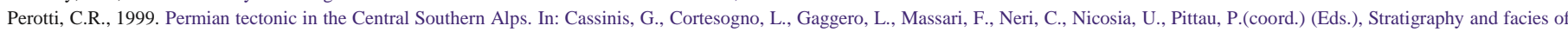
the Permian deposits between eastern Lombardy and the western Dolomites. International Congress on: "The continental Permian of the Southern Alps and Sardinia (Italy). Regional reports and general correlations", Brescia 15-25 September 1999, Field trip guide-book, pp. 19-20.

Pickerill, R.K., 1994. Nomenclature and taxonomy of invertebrate trace fossils. In: Donovan, S.K. (Ed.), The Palaeobiology of Trace Fossils. John Wiley and Sons, New York, pp. 3-42.

Pickerill, R.K., Narbonne, G.M., 1995. Composite and compound ichnotaxa: a case example from the Ordovician of Quebec, eastern Canada. Ichnos 4, 53-69.

Rindsberg, A.K., Martin, A.J., 2003. Arthrophycus in the Silurian of Alabama (USA) and the problem of compound trace fossils. Palaeogeogr. Palaeoclimatol. Palaeoecol. 192, 187-219.

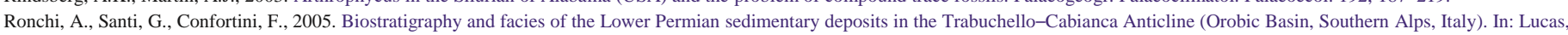
S.G., Ziegler, K.E. (Eds.), The Nonmarine Permian. New Mexico Museum of Natural History and Sciences Bull., 30, pp. $273-281$.

Santi, G., 1999. Icniti di tetrapodi permiani nelle Alpi Bergamasche. Nota preliminare. Rend. Sc. B, 133. Istituto Lombardo, pp. 41-50.

Santi, G., 2003. Early Permian tetrapod ichnology from the Orobic Basin (Southern AlpsNorthern Italy). Data, problems, hypotheses. Boll. Soc. Geol. Ital. 2, 59-66.

Santi, G., 2005. Lower Permian palaeoichnology from the Orobic Basin (Northern Alps). GeoAlp 2, 77-90.

Santi, G., Krieger, C., 2001. Lower Permian tetrapod footprints from Brembana Valley- Orobic Basin (Lombardy, Northern Italy). Rev. Paléobiol. $20,45-68$.

Sarjeant, W.A.S., 1979. Code for trace fossil nomenclature. Palaeogeogr. Palaeoclimatol. Palaeoecol. 28, 147-167.

Schaeffer, B., 1941. The morphological and functional evolution of the tarsus in amphibians and reptiles. Bull. Am. Mus. Nat. Hist. 78, 398-472.

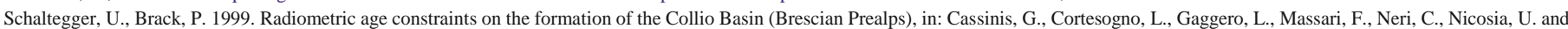
Pittau, P. (coord.), Stratigraphy and facies of the Permian deposits between eastern Lombardy and the western Dolomites. International Congress on: "The continental Permian of the Southern Alps and Sardinia (Italy). Regional reports and general correlations". Brescia 15-25 September 1999, Field trip guide-book, 71.

Schweigert, G., 2001. Eine Schwimmspur aus dem Nusplinger Plattenkalk (Oberjura, SW-Deutschland). N. Jb. Geol. Paläont. Monatsh. 2001, 77-84.

Sciunnach, D., 2001. The Lower Permian in the Orobic Anticline (Southern Alps, Lombardy): review based on new stratigraphic and petrographic data. Riv. Ital. Paleontol. Stratigr. 107, 47-68.

Thulborn, R.A., Wade, M., 1989. A footprint as history of movement. In: Gillette, D., Lockley, M.G. (Eds.), Dinosaur Tracks and Traces. Cambridge University Press, Cambridge, pp. 51-56.

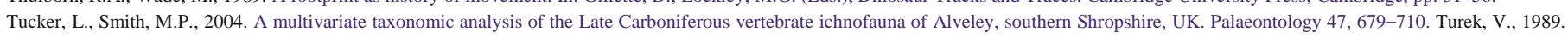
Fish and amphibian trace fossils from Westphalian Sediments of Bohemia. Palaeontology 32, 623-634.

Voigt, S., Saber, H., Schneider, J.W., Hmich, D., Hminna, A., 2011. Late Carboniferous-Early Permian tetrapod ichnofauna from the Khenifra Basin, Central Morocco. Geobios 44, 399-407.

Walter, H., 1983. Zur Taxonomie, Ökologie und Biostratigraphie der Ichnia limnischterrestrischer Arthropoden des mitteleuropäischen Jungpaläozoikums. Freib. Forsch. C 382, 146-193.

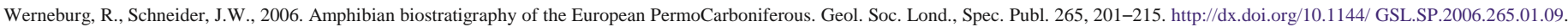

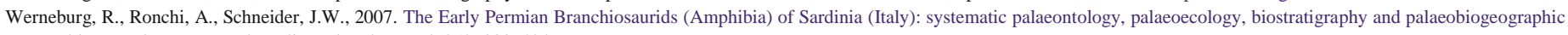
problems. Palaeogeogr. Palaeoclimatol. Palaeoecol. 252, 383-404.

Woodworth, J.B., 1900. Vertebrate tracks on Carboniferous shales of Plainville, Massachusetts. Geol. Soc. Am. Bull. 11, 449-454. 